研究

\title{
高温焼結した低合金鋼の疲労強度に及ぼす漫炭焼入れ並びにショットピーニングの影響
}

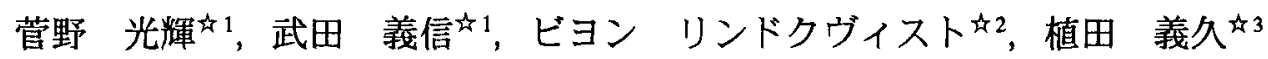 \\ タ1ヘガネスジャパン桻，广107-0052 港区赤坂4-2-19. \\ か2ヘガネス $\mathrm{AB}, \mathrm{S}-26383$ ヘガネス, スエーテン. \\ 《3(怢)ファインシンター, 于 607-8201 京都市山科区栗栖野狐塚 5-1.
}

\section{Influence of Shot-peening and Carburizing on Fatigue Strength of High Temperature Sintered Steel}

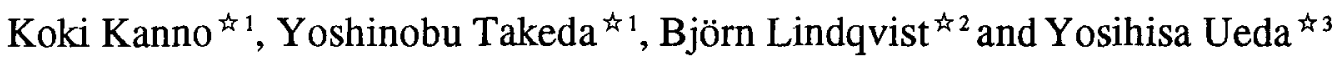 \\ ${ }^{1}$ Höganăs Japan K.K., 4-2-19, Akasaka Minato-ku, Tokyo 107-0052. \\ ${ }_{42}^{2}$ Höganäs AB, S-263 83 Höganäs, Sweden. \\ 33ine Sinter Co.,LTD., 5-1 Kitsunezuka Kurisuno Yamashina-ku, Kyoto 607-8201.
}

Received May 15, 2003

\section{SYNOPSIS}

Partially diffusion bonded alloy has been used for components which require high mechanical properties. Secondary operations as a Carburizing are used for these materials to achieve higher strength. Prealloyed $3 \mathrm{Cr}-0.5 \mathrm{Mo}$ powder can have excellent mechanical properties when it is sintered at $1250^{\circ} \mathrm{C}$. Though this material has introduced in the market in 1998, it has not been evaluated completely about Fatigue Strength after Carburizing and Shot Peening Process that are common process to achieve higher fatigue strength in wrought steels. Considerations when applying such secondary operations to these materials in different conditions are given in this paper.

KEY WORDS

Cr-alloyed PM-steels, Fatigue Strength, Mesh Belt Furnace, High Temperature Sintering

\section{1 緒 言}

粉末冶金用鉄粉及び鋼粉の $80 \%$ 以上が自動車用部品に使用 されている.自動車用構造部品に要求される特性は高性能で あり完成品として低コストであることである，従って理想的 な構造部品材料としては，(1)低コスト，(2)容易に思い通りの 形状が得られること, (3)比強度が高いこと等が挙げられる.

今までは 4 mass\% $\%$ i- 1.5 mass $\% \mathrm{Cu}-0.5$ mass\% $\%$ o 系部分拡散 合金鋼粉が高性能部品用材料として使用され続けている。こ れを補完する材料として 3 mass\% $\%$ r- 0.5 mass\% $\%$ oの予合金鋼 粉材料が 1998 年に紹介され た性質を示す事例が報告されているで、。

ところが粉末冶金材料の静的なデー夕は豊富であるが, 疲 労等の動的強度のデータが不足しているのが現状である.これ が粉末冶金部品の桩大を妨げる1つの要因となっている. 2001 年に検索したところ数例の報告が認められだけであった ${ }^{5}$. 精 造部品を設計するにあたり疲労強度は避けて通れない検討事 項であり, 今後疲労強度デー夕の充実が望まれる.

疲労強度に及ぼす要因として，(1)密度，(2)硬度，(3)金属組 織 (介在物・欠陥)，(4)表面粗さ，(5)残留応力等がある．溶製
材においてこれらの研究は大いに行われているが，粉末冶金 材料については残留応力関係の研究発表が少ないのが現状で ある。

そこで焼結後の工程において疲労強度に及ぼす要因を調べ る事は粉末冶金材料の今後の搪大に大いに役立つ事と考えら れる.ここでは疲労強度向上に奇与する唚炭焼入れ工程と ショットピーニング工程に着目し，金属組織及び工程の影響 について調べ，溶製材との違いについて述べる.

\section{2 実鈳方法}

\section{1 材料}

粉末材料として従来から使用されている4mass\%Ni-1.5mass\% $\mathrm{Cu}-0.5$ mass\% $\%$ 部分拡散合金鋼粉 (以下DistaloyAE)及びこれ 之同等以上の機械的性質を有する 3 mass $\% \mathrm{Cr}-0.5 \mathrm{mass} \% \mathrm{Mo}$ 予 合金鋼粉 (以下 AstaloyCrM) を用い Table 1 に示す組成の材料

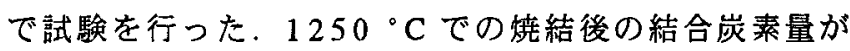
AstaloyCrMでは 0.4mass\%に, DistaloyAEでは 0.5 mass\%にな るように黒鉛を添加し，浸炭焼入れ用としてはAstaloyCrMは $0.2 \%$ の結合炭素量になるよう添加黒鈶量を調整し, DistaloyAE 
Table 1 Powder Compositions.

\begin{tabular}{|c|c|c|c|c|}
\hline No. & Base Material & Graphite & Lubricant & Note \\
\hline 1 & $\begin{array}{c}\text { Fe-4\%Ni-1.5\%Cu-0.5\%Mo } \\
\text { (DistaloyAE) }\end{array}$ & $0.5 \%$ & $0.6 \%$ & \\
\hline 2 & $\begin{array}{c}\text { Fe-4\%Ni-1.5\%Cu-0.5\%Mo } \\
\text { (DistaloyAE) }\end{array}$ & Nothing & $0.6 \%$ & Carburizing \\
\hline 3 & $\begin{array}{c}\text { Fe-3\%Cr-0.5\%Mo } \\
\text { (AstaloyCrM) }\end{array}$ & $0.5 \%$ & $0.6 \%$ & \\
\hline 4 & $\begin{array}{c}\text { Fe-3\%Cr-0.5\%Mo } \\
\text { (AstaloyCrM) }\end{array}$ & $0.3 \%$ & $0.6 \%$ & Carburizing \\
\hline
\end{tabular}

Table 2 Conditions of Shot Peening Process.

\begin{tabular}{|l|l|l|l|}
\hline \multicolumn{2}{|c|}{ CSP } & \multicolumn{1}{c|}{ U } \\
\hline Type & Air Nozzle Type & Type & Ultrasonic Type \\
\hline Shot & RCW06PH & Shot & SUJ2 OD0.6mm \\
\hline Air pressure & $0.3 \mathrm{MPa}$ & Quantity of Shot & $3.04 \mathrm{~g}$ \\
\hline Peening time & $15 \mathrm{sec}$ & Peening Time & $360 \mathrm{sec}$ \\
\hline Distance to work & $150 \mathrm{~mm}$ & Distance to work & $200 \mathrm{~mm}$ \\
\hline Arc Height & $0.32 \mathrm{mmA}$ & Amplitude & $90 \mu$ \\
\hline Work Revolutions & $12 \mathrm{rpm}$ & Frequency & $20 \mathrm{kHz}$ \\
\hline & & Arc Height & $0.487 \mathrm{mmN}$ \\
\hline & & Work Revolutions & $12 \mathrm{rpm}$ \\
\hline
\end{tabular}

は黒鉛無添加とした．また全ての材料に温間成形用の潤滑凧 を $0.6 \mathrm{mass} \%$ 添加している.

\section{2 成形焼結}

各粉末材料を $140^{\circ} \mathrm{C}$ 加熱後 $800 \mathrm{MPa}$ で温間成形し, $1250^{\circ} \mathrm{C}$ $\times 30$ 分分解アンモニアガス $(\mathrm{DA})$ 雾囲気中で焼結した。

2.3 浸炭焼入焼戻

焼結体の一部は浸炭焼入焼戻処理を施している，

$860^{\circ} \mathrm{C} \times 90$ 分 C.P. $=0.8 \%, 80^{\circ} \mathrm{C}$ の油焼入, $200^{\circ} \mathrm{C} \times 90$ 分焼戻 2.4 ショットピーニング

焼結体の一部と浸炭焼入焼戻処理品の一部にショットピー ニング処理を行い, その効果について調べた. Table 2 に通常 ショットピーニング処理 (エアノズル式) と超音波ショット ピーニング処理(超音波による振動エネルギーでショットが往 復運動を繰り返すところに試験片を曝す方法) の条件を示し た.

\section{5 疲労強度試験}

疲労強度試験はFig.1に示す試験片を用い，段階法による平 面曲げ疲労試験方法で行った．応力比 $\mathrm{R}=-1$ に設定し，周波 数 $25 \mathrm{~Hz}$ の 4 点曲げ疲労試験であり，50\%の破壊確率を 200 万 回までの繰り返し数で求めた。試験機の外笅を Fig.2に示す.

\section{3 実験結果および考察}

3.1 化学分析

焼結後に狙いの宸素量が得られたことを確認する為にLeco

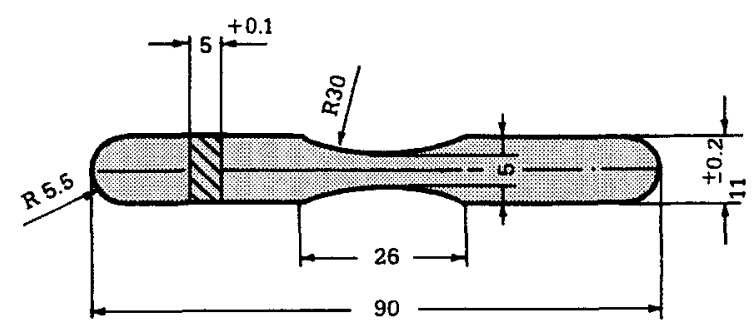

Fig.1 Shape of Fatigue Strength Bars.

CS344にて計測した. また過剰に酸化していないことの確認 にはLecoTC136を用いて酸素濃度を得ている. Table 3に各試 料の焼結後の化学分析值を示す. DistaloyAE及びAstaloyCrM の両者共に予測通りの炭素濃度が得られ，また高温焼結によ り酸素濃度の低減が可能であった. $\mathrm{Ni} \cdot \mathrm{Cu} \cdot \mathrm{Mo}$ の部分拡散合 金鋼粉の焼結容易性は Gibbs の自由エネルギー線図から明確 であるが，酸素親和力の強いCr 不含む AstaloyCrMにおいて も 0.01 mass\%レベルまで酸素量を低減可能であった.これら は次の合金鋼の酸化還元平衡から説明できる。

$$
\begin{aligned}
& \Delta \mathrm{G}^{\circ}=\mathrm{A}+\mathrm{BT} \log \mathrm{T}+\mathrm{CT}=-\mathrm{RT} \ln \mathrm{K} \\
& 2 \mathrm{Cr}+2 / 3 \mathrm{O}_{2}=\mathrm{Cr}_{2} \mathrm{O}_{3} \quad \mathrm{~K}=1 /\left(\mathrm{aCr}^{2} * \mathrm{PO}_{2}^{2 / 3}\right) \\
& \mathrm{PO}_{2}=\exp \left(2 \Delta \mathrm{G}^{\circ} /(3 * 1.987 * \mathrm{~T})\right) / \mathrm{aCr}
\end{aligned}
$$




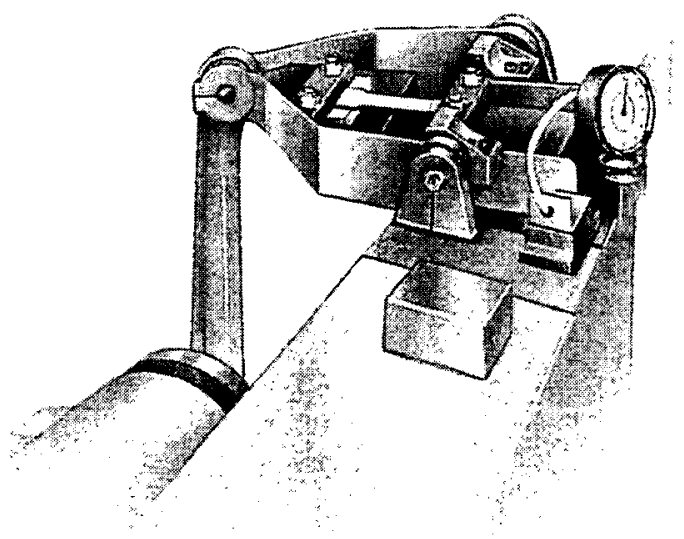

Fig.2 Equipment of Fatigue Strength Test.

一方 $\left.\Delta \mathrm{G}^{\circ}(\mathrm{cal})=-267,750+62.1 \mathrm{~T}^{6}\right)$ から各温度での $\Delta \mathrm{G}^{\circ}$ が求 まる.ここでRは気体定数である．また各合金のCrの活量が

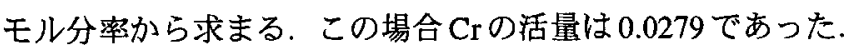
故に平衡定数 $\mathrm{K}$ が求まり，各温度での $\mathrm{PO}_{2}$ が求まる.

今回の焼結温度 $1250^{\circ} \mathrm{C}$ における AstaloyCrM の平衡酸素分 圧は3.19 $\times 10^{-15} \mathrm{~atm}$ であった. また通常の分解アンモニアガス (DA) 雲囲気中の酸素分圧は $1.31 \times 10^{-17} \mathrm{~atm}$ であるから熱力学 的平衡からみて $\mathrm{Cr}$ 合金は還元可能である. DistaloyAEは Feに $\mathrm{Ni} \cdot \mathrm{Cu} \cdot \mathrm{Mo}$ を部分拡散合金接合しており，自由エネルギ一線 図から判断して勿論容易に還元される.

また含有されているCによる $\mathrm{Cr}_{2} \mathrm{O}_{3}$ の還元反忘は

$$
\mathrm{Cr}_{2} \mathrm{O}_{3}+3 \mathrm{C}=2 \mathrm{Cr}+3 \mathrm{CO} \quad \mathrm{K}=\mathrm{aCr}^{2} *\left(\mathrm{P}_{\mathrm{CO}}\right)^{3}
$$

この反心の $1250^{\circ} \mathrm{C}$ における $\Delta \mathrm{G}^{\circ}$ は $\Delta \mathrm{G}^{\circ}(\mathrm{cal})=187,650-124.95 \mathrm{~T}^{\text {の }}$ から求まる. Crの活量を考慮するとCOの平衡分圧は $14.6 \mathrm{~atm}$ となり，平衡は右に進み炭素が $\mathrm{Cr}$ 酸化物を還元する．これが 焼結後に炭素量が減少した理由である.

ここで添加黒鈶量と焼結後の炭素量を比較すると $0.15 \mathrm{mass} \%$ の損失があり，この損失は上記反応でCOとして損 失すると考えると重量比で $\mathrm{C}: \mathrm{O}=12: 16=3: 4$ である. 従って 損失した炭素が全て還元に寄与したと仮定すると還元された 酸素量は $0.15 \times 4 / 3=0.20$ mass\% となる. 当初含まれていた酸 素量が 0.21 mass\%であるから妥当な値となる.

従って本焼結中に添加黒鉛による $\mathrm{Cr}_{2} \mathrm{O}_{3}$ の還元反応が生じ， 良好な焼結が実現したものと考えられる。

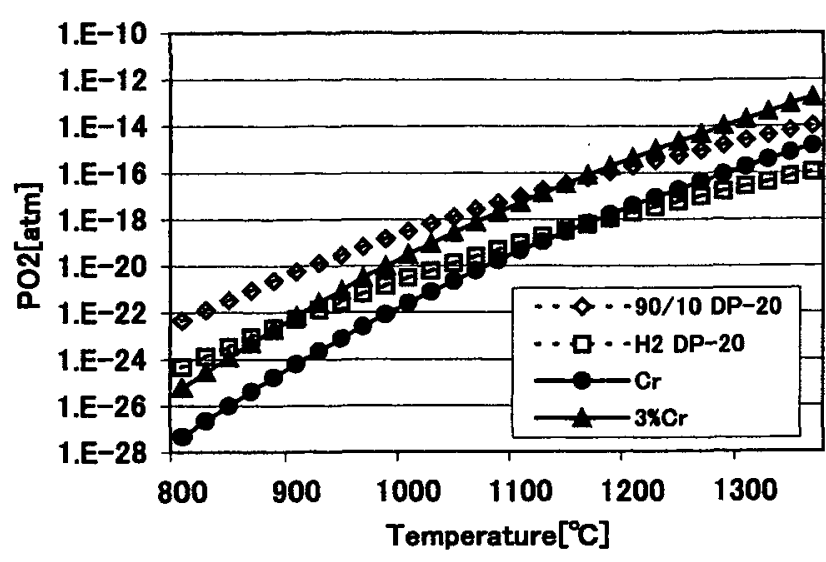

Fig.3 Partial pressures of Oxygen of $\mathrm{Cr}$ materials and Nitrogen based Atmospheres.

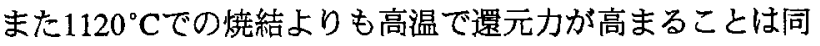
様の計算により, 高温でのAstaloyCrMの平衡酸素分圧と雾团 気の平衡酸素分珐との差が高温程大きくなることから理解で きる. Fig. 3 に純水素雾团気と $90 \mathrm{~N}_{2} / 10 \mathrm{H}_{2}$ 䨌团気の場合におい て, 本材料と純 $\mathrm{Cr}$ の各温度における平衡酸素分圧の計算結果 を示す.以上のことは焼結後の酸素分析結果に表われており， 高温程, 還元されていることが証明された.

3.2 静的機械的性質

焼結及び浸炭焼入焼戻後の静的機械的性質をTable 4 に示 す.

冷却速度 $0.5^{\circ} \mathrm{C} / \mathrm{sec}$ においてDistaloyAE+0.5mass\%Cの場合, パーライト/ベイナイト組織が 50\%，マルテンサイト組織が 40\%, フェライト組織が10\%である.一方AstaloyCrM+0.4mass\% Cの場合は，ベイナイト組織が 90\%，マルテンサイト組織が $10 \%$ となる.

密度一定として各相の硬度から強度を推定し》, 奇与率を相 の比率で各材料の焼結後の引張強度を推定する. 結果は以下 の通りである.

DistaloyAE (密度 $7.48 \mathrm{~g} / \mathrm{cm}^{3}$ ) の場合 :

TTS $=(0.5 \times 870+0.4 \times 1695+0.1 \times 500) \times 0.90=1047 \mathrm{MPa}$

AstaloyCrM(密度 $7.38 \mathrm{~g} / \mathrm{cm}^{3}$ ) の場合：

$\mathrm{TS}=(0.9 \times 930+0.1 \times 1695) \times 0.85=855 \mathrm{MPa}$

Table 3 Chemical Analysis after sintering.

\begin{tabular}{|c|c|c|c|c|}
\hline No. & Material & C & O & Note \\
\hline 1 & DistaloyAE+0.5\%Gr. & $0.48 \%$ & $0.02 \%$ & After sintering \\
\hline 2 & DistaloyAE & $<0.01 \%$ & $0.01 \%$ & $=$ ditto $=$ \\
\hline 3 & AstaloyCrM+0.5\%Gr. & $0.35 \%$ & $0.01 \%$ & $=$ ditto $=$ \\
\hline 4 & AstaloyCrM+0.3\%Gr. & $0.16 \%$ & $0.01 \%$ & $=$ ditto $=$ \\
\hline
\end{tabular}


Table 4 Mechanical Properties of Sintered Specimens.

\begin{tabular}{|l|l|c|c|c|c|}
\hline & SP. & $\begin{array}{c}\text { Hardness } \\
\text { on Surface } \\
{[\mathrm{Hv10]}}\end{array}$ & $\begin{array}{c}\text { Tensile } \\
\text { Strength } \\
{[\mathrm{MPa}]}\end{array}$ & $\begin{array}{c}\text { Elongation } \\
{[\%]}\end{array}$ & $\begin{array}{c}\text { Impact } \\
\text { Energy } \\
{[\mathrm{J}]}\end{array}$ \\
\hline \multirow{2}{*}{$\begin{array}{l}\text { DistaloyAE } \\
0.48 \% \mathrm{C}\end{array}$} & No & 290 & 864 & 3.34 & 34 \\
\hline & Yes & 468 & 873 & 2.91 & 33 \\
\hline $\begin{array}{l}\text { DistaloyAE } \\
\text { Carburizing }\end{array}$ & No & 468 & 950 & 2.96 & 25 \\
\cline { 2 - 6 } $\begin{array}{l}\text { AstaloyCrM } \\
0.35 \% C\end{array}$ & Yes & 635 & 975 & 2.85 & 23 \\
\hline \multirow{2}{*}{$\begin{array}{l}\text { AstaloyCrM } \\
0.16 \% C \text { Carburizing }\end{array}$} & Yes & 481 & 873 & 3.81 & 39 \\
\cline { 2 - 6 } & No & 539 & 874 & 3.60 & 38 \\
\cline { 2 - 6 } & Yes & 689 & 1015 & 1.30 & 23 \\
\hline
\end{tabular}

Table 5 Fatigue Strength and Residual Stress for each process condition.

\begin{tabular}{|c|c|c|c|c|c|c|}
\hline Material & $\begin{array}{l}\text { Sintered } \\
\text { Density } \\
{\left[\mathrm{g} / \mathrm{cm}^{3}\right]}\end{array}$ & Carburizing & $\begin{array}{c}\text { Shot } \\
\text { Peening }\end{array}$ & $\begin{array}{l}\text { Fatigue } \\
\text { Strength } \\
{[\mathrm{MPa}]}\end{array}$ & $\begin{array}{c}\text { Surface } \\
\text { Residual } \\
\text { Stress } \\
{[\mathrm{MPa}]}\end{array}$ & $\begin{array}{c}\text { Maximum } \\
\text { Residual } \\
\text { Stress } \\
{[\mathrm{MPa}]}\end{array}$ \\
\hline \multirow{3}{*}{$\begin{array}{l}\text { DistaloyAE } \\
+ \\
0.48 \% \mathrm{C}\end{array}$} & \multirow[t]{3}{*}{7.48} & \multirow[t]{3}{*}{ No } & No & 210 & - & - \\
\hline & & & CSP & 340 & -584 & -697 \\
\hline & & & USP & 340 & -739 & -739 \\
\hline \multirow[t]{3}{*}{ DistaloyAE } & \multirow[t]{3}{*}{7.53} & \multirow[t]{3}{*}{ Yes } & No & 390 & - & - \\
\hline & & & $\mathrm{CSP}$ & 390 & -818 & -1064 \\
\hline & & & USP & 390 & -910 & -1068 \\
\hline \multirow{3}{*}{$\begin{array}{l}\text { AtaloyCrM } \\
+ \\
0.35 \% \mathrm{C} \\
\end{array}$} & \multirow[t]{3}{*}{7.38} & \multirow[t]{3}{*}{ No } & No & (310) & -69 & -93 \\
\hline & & & $\mathrm{CSP}$ & 390 & -588 & -694 \\
\hline & & & USP & 390 & -656 & -715 \\
\hline \multirow{3}{*}{$\begin{array}{l}\text { AstaloyCrM } \\
+ \\
0.16 \% \mathrm{C} \\
\end{array}$} & \multirow[t]{3}{*}{7.39} & \multirow[t]{3}{*}{ Yes } & No & 470 & -100 & -146 \\
\hline & & & CSP & 420 & -654 & -1065 \\
\hline & & & USP & 470 & -943 & -1243 \\
\hline
\end{tabular}

Table 4の実測值と比較すると均一組織のAstaloyCrMでは各 相毎の奇与率で或る程度の引張強度が推定可能であり，不均 一組織ではフューズとなる或る相の影響により一概に各相の 強度分担率で述べられないと考えられる。

AstaloyCrMにおいて硬度, 引張強度等がDistaloyAEより向 上していることは上記から説明できる.

次に通常ショットピーニング処理が機械的性質にどのよう な影響を与えるかについて調查した. 何れの材料においても 処理後に表面ヴィッカース硬度が向上し引張強度もやや向上 するが，伸び・衝撃值が低下する．これは表面に加工誘起マ ルテンサイトが表われ，その影響が相対的に試験片の深い部 分にまで表われた為と考えられる.このことから部品の断面 糟に応じた深さ方向の表面処理勃果を最適化することが重要 であるのがわかる.

\section{3 疲労強度}

焼結及び浸炭焼入れ後の疲労強度を残留応力と共にTable 5
に示した. 結果として高温焼結品において部分搪散合金材料 であるDistaloyAEよりも予合金鋼材料のAstaloyCrMにおいて 高い疲労強度が得られた．これは或る程度高温焼結品におい てAstaloyCrMの静的機械的性質が優れている結果から予測さ れることであるが, 引張強度に対する疲労強度の比に着目し てみると不均一組織である DistaloyAE材料よりも均一組織で あるAstaloyCrM材料の疲労強度比が約 0.1 高くなっ.ている.こ のことから高疲労強度を要求される部品には強度レベルから だけ判断するとAstaloyCrMのような均一組織材料が適してい る.ここでDistaloyAE製の焼結体の疲学強度比が小さい. 平 面曲げ波労強度試験方法を採用したことにもよるが表面組織 の制御不足も考えられる.

疲労限度線图から推定すると主に降伏強度の奇与が大きい と考えられる. Table 6に降伏点強度に対する疲労強度の比も 同時に示した. 引張強度に対する比よりもより一定值に近付 く.よって定性的に降伏強度が高い程, 疲労強度の向上に奇 
Table 6 Fatigue Strength Ratio against Tensile Strength and Yield Strength.

\begin{tabular}{|c|c|c|c|c|c|}
\hline Material & Carburizing. & $\begin{array}{l}\text { Shot } \\
\text { Peening }\end{array}$ & $\begin{array}{c}\text { Fatigue Ratio } \\
\text { F.S. / T.S. }\end{array}$ & $\begin{array}{c}\text { Yield } \\
\text { Strength } \\
\text { [MPa] }\end{array}$ & $\begin{array}{l}\text { Fatigue Ratio } \\
\text { F.S./Y.S. }\end{array}$ \\
\hline \multirow{3}{*}{$\begin{array}{l}\text { DistaloyAE } \\
+ \\
0.48 \% \mathrm{C}\end{array}$} & \multirow[t]{3}{*}{ No } & No & 0.24 & 450 & 0.47 \\
\hline & & CSP & 0.39 & - & - \\
\hline & & USP & 0.39 & - & - \\
\hline \multirow[t]{3}{*}{ DistaloyAE } & \multirow[t]{3}{*}{ Yes } & No & 0.41 & 690 & 0.56 \\
\hline & & CSP & 0.40 & - & - \\
\hline & & USP & 0.40 & - & - \\
\hline \multirow{3}{*}{$\begin{array}{l}\text { AtaloyCrM } \\
+ \\
0.35 \% \mathrm{C}\end{array}$} & \multirow[t]{3}{*}{ No } & No & 0.36 & 620 & 0.50 \\
\hline & & $\mathrm{CSP}$ & 0.45 & - & - \\
\hline & & USP & 0.45 & - & - \\
\hline \multirow{3}{*}{$\begin{array}{l}\text { AstaloyCrM } \\
+ \\
0.16 \% \mathrm{C}\end{array}$} & \multirow[t]{3}{*}{ Yes } & No & 0.48 & 730 & 0.64 \\
\hline & & CSP & 0.41 & - & - \\
\hline & & USP & 0.46 & - & - \\
\hline
\end{tabular}

\section{Bending Fatigue Test DistaloyAE $+0.5 \% \mathrm{C}$}

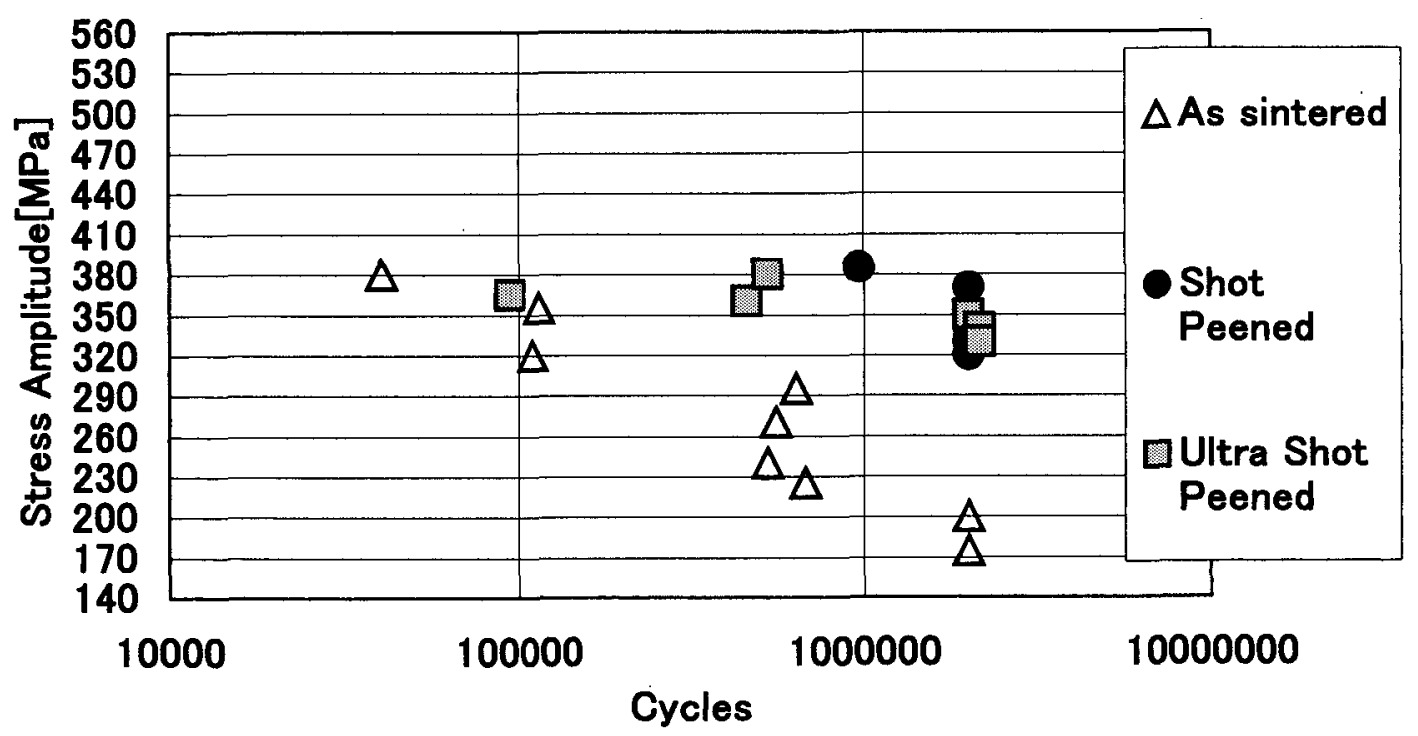

Fig.4 Fatigue Strength of DistaloyAE with $0.5 \% \mathrm{C}$ after sintering.

与すると考えられる．材料疲労強度の予測化の為に更にデー タの蓄積を行って行く.

ショットピーニング処理の効果は焼結後に行うことで顕著 なる向上が認められる.これは表面に加工誘起マルテンサイ 卜組織の硬化領域が表出し，それに伴う圧縮残留芯力により 説明できるであろう. 同様の理由により浸炭処理も疲労強度 向上にかなり有効であった。但し，今回の実験では浸炭焼入 後のショットピーニング処理の効果を明確に示すことができ なかった．考えられる要因として，(1)ショットピーニング処
理時のエッジ欠陥，(2)表面近傍組織の見落とし，(3)ショット ピーニング処理前組織のチューニング不足等が考えられるが， これらについては再実験中である. 特に疲労の初期クラック 発生に関する研究 ${ }^{8}$ は試験方法についての再考を示唆してい る. DistaloyAE と AstaloyCrMの焼結体の疲労強度向上例をそ れぞれ Fig.4及び Fig.5に示す.

3.4 表面粗さ

応力集中という点から表面粗さも疲労強度に影響を与える 因子の 1 つである．加工した表面状態により疲労強度が異な 


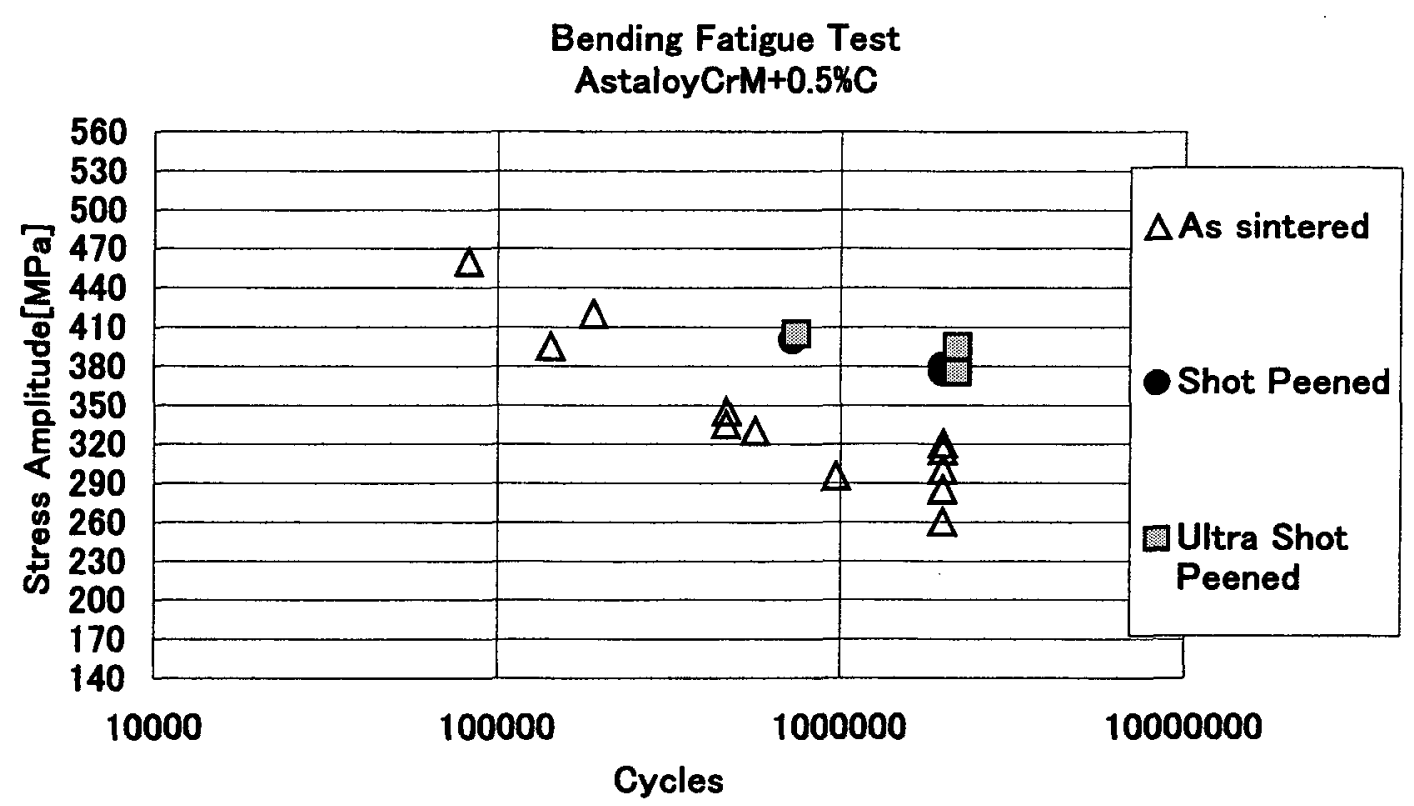

Fig.5 Fatigue Strength of AstaloyCrM with $0.35 \% \mathrm{C}$ after sintering.

Table 7 Roughness of each specimens before and after conventional shot peening or ultra shot peening.

\begin{tabular}{|c|c|c|c|}
\hline & Material & $\begin{array}{c}\mathrm{Rz}(\mu \mathrm{m}) \\
\text { before S.P. }\end{array}$ & $\begin{array}{c}\mathrm{Rz}(\mu \mathrm{m}) \text { after S.P. } \\
\text { CSP/USP }\end{array}$ \\
\hline 1 & $\begin{array}{c}\text { DistaloyAE + 0.5\%Gr } \\
\text { Sintered Parts }\end{array}$ & 9.02 & $29.60 / 8.58$ \\
\hline 2 & $\begin{array}{c}\text { DistaloyAE } \\
\text { Carburizing \& Tempering }\end{array}$ & 7.45 & $9.90 / 3.94$ \\
\hline 3 & $\begin{array}{c}\text { AstaloyCrM + 0.5\%Gr. } \\
\text { Sintered Parts }\end{array}$ & 8.99 & $24.10 / 6.95$ \\
\hline 4 & $\begin{array}{c}\text { AstaloyCrM + 0.5\% Gr. } \\
\text { Carburizing \& Tempering }\end{array}$ & 9.06 & $6.00 / 4.50$ \\
\hline
\end{tabular}

るのは知られている 9 ,10)，そこで焼結後及び浸炭後表面・ ショットピーニング処理後における表面粗さの変化を調べた 結果をTable 7に示した. 計測は断面曲線を十点平均粗さであ るRzで表した(JIS B0601-1982). これから通常ショットピー ニングを暁結後品に適用すると，かなりの肌荒れが生じるこ とがわかる.また浸炭処理後に通常ショットピーニング处理 を適用した場合は表面粗さが著しく悪くなることは無かった. 一方超音波ショットピーニング処理においては浸炭前の焼結 体に適用しているにも関わらず，表面粗さは改善する傾向に ある. 今後の高強度材料開発の有効な指針となるであろう.

表面粗さの低下により疲労強度の低下が懸念されたが，本 材料において Rzが 20 ミクロン以上であっても圧縮残留応力 の寄与により疲労強度が向上することがわかる.

\section{5 圧縮残留応力}

圧縮残留応力についてはCr管球を用いたX線応力測定装置 にて表面から深さ方向にエッチング除去しながら深さ方向の 压縮残留応力分布を計浿した，その結果については前出の
Table 5に示している. また通常ショットピーニング処理と超 音波ショットピーニング処理時の圧縮残留応力分布を梁さ方 向に計測したのが Fig.6 及び Fig.7である. 疲労強度向上には 疲労亀裂発生を抑制し, 疲労の伝播を達くすることが大切で ある. 表面硬化や表面圧縮残留応力の付与は前者に貢献し， 有効硬化深さを增加させること及び圧縮残留応力分布の領域 拡大は後者に貢献する，実際の部品では両者を考慮した工程 が考慮されている. 二段ピーニング処理等はその典型例であ る.

表面の圧縮残留応力の寄与を試験片に作用する引張応力分 布を考えれば，表面の圧縮残留応力は表面の平均応力を圧縮 側にシフトさせる. これが疲労強度の向上に奇与することに なる. 疲労限度線図の平均応力が負側へ(圧維側へ)シフトし たことと同一である. つまり応力比 $\mathrm{R}=\sigma_{\min } / \sigma_{\max }$ が -1 より小 さいと疲労破壊までの応力振幅は大きくなり，これより大き いと平均応力が正側へ(引張側へ)シフトし, 疲労限までの応 力振幅は小さくなる. 


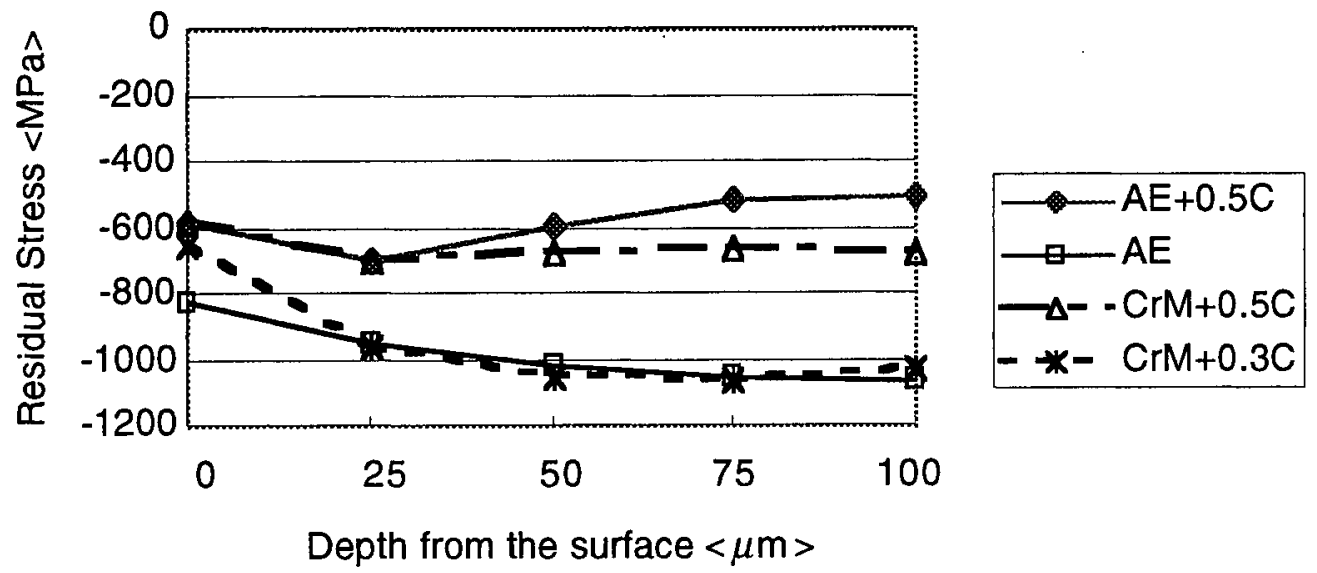

Fig.6 Profile of Residual Stress after Conventional Shot Peening.

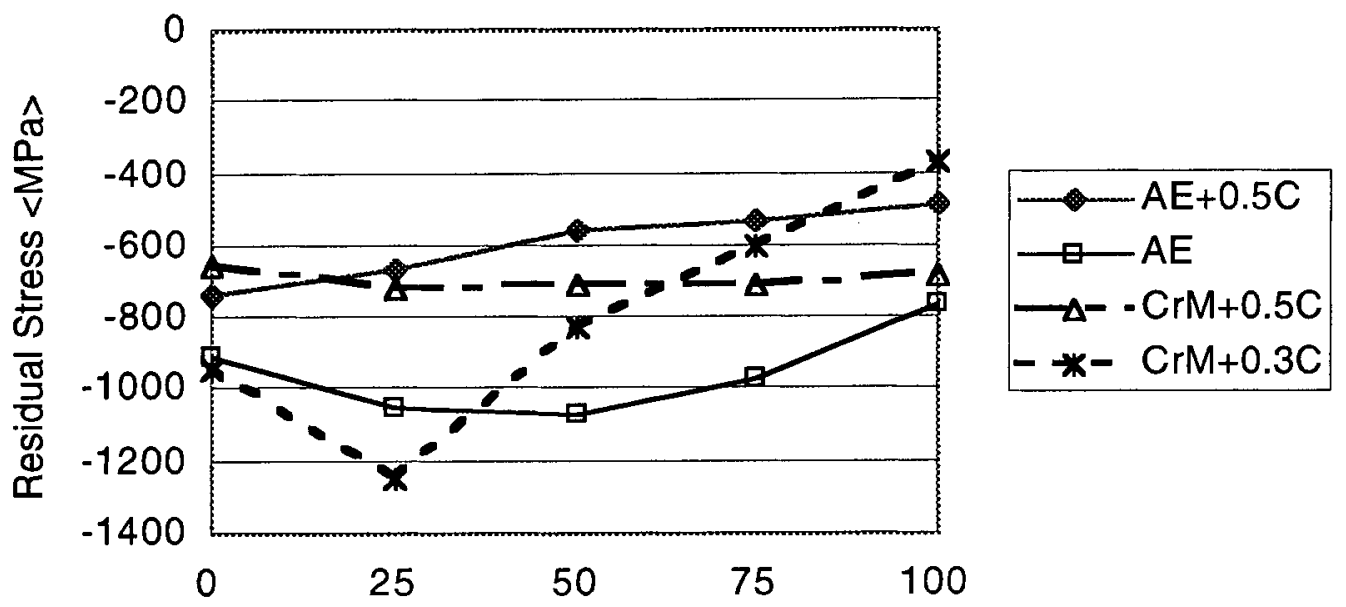

Depth from the surface $<\mu \mathrm{m}>$

Fig.7 Profile of Residual Stress after Ultra Shot Peening.

殆どの実部品では 3 次元的に応カプロファイルを考察しな ければならない。このことは梁さ方向で変化して行く負荷応 カプロファイル・硬度又は金属組織の変化・残留応力分布の 変化等を全て考慮する必要がある.

超音波ショットピーニング処理後の残留応力分布が浅く， しかも Fig.4 及び Fig.5 の S-N曲線の傾きが小さい.この理由 は曲げモーメントが加わったときの高負荷時と低負荷時の深 さ方向の応力分布から説明可能である.つまり高負荷時にお いては表面の引張応力が増加し, 応力プロファイルの傾きが 大きくなるため, 表面近傍で負荷と压縮残留応力の合力の ピークが発生し易い. Fig.8は上面に引張・下面に圧縮のモー メントが働いた場合の模式図であり，一点鎖線は応力の中立 軸を示す. 曲線部分が残留応力効果である. よって亀裂発生 後は疲労破断面の割合が小さく静的破断面の割合が増加する. これが表面圧縮残留応力のみを増加させても高負荷側で疲労 寿命が向上しない理由である.よって S-N曲線の傾きが小さ くなる理由であると考えられる. 疲学亀裂の進展速度を抑制

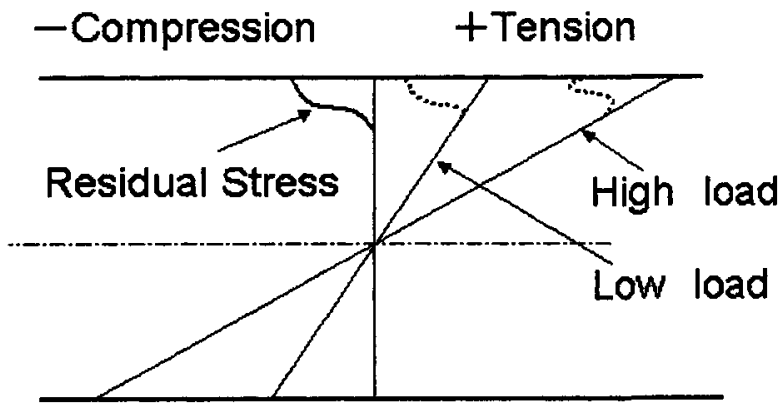

Fig.8 Schematic Drawings of residual stress of Fatigue Strength Bars when bended.

する為にも残留応カプロファイルは或る程度の深さまで必要 である。

残留応力分布の効果及びシミュレーションについては幾つ

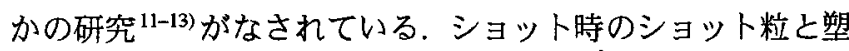


性域の模式図を Fig.9に示す．また溶製材料のSCM420Hを浸 炭娃入した材料にショットピーニングを行い，圧縮残留応力 分布の実測値とY.F Al-Obaidの式 ${ }^{12}$ による計算で最大圧縮残 留応力深さ $\alpha \mathrm{h}_{\mathrm{p}}$ の倸数 $\alpha$ を 0.15 として求めたピーク值をFig. 10 に示した.

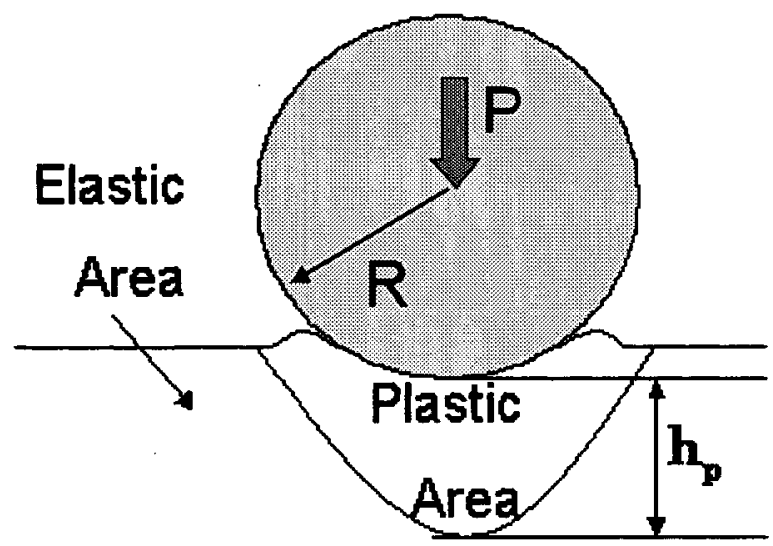

Fig.9 Schematic Drawings when shot peened.
実測值とのずれが生じた理由として金属組織・硬度が表面 から内部へと徐々に変化していることが考えられる.これを ぞう計算に取り入れるかが今後の課題である.

\section{6 肌焼鋼との比較}

歯車等の高強度用材料として代表的なものが JIS 規格 SCM420等の浸炭焼入肌焼鋼である. 最近の小型化の要求に 伴い部品の高強度化が図られており，その1つの手法が浸炭 焼入焼戻し後のショットピーニング処理である ${ }^{14,15)}$ ，その疲労 強度向上のプロセスを現時点で比較したものがTable 8 であ る. また引張強度と波学強度との関係を模式的に示したのが Fig.11である. 小さいダイヤ印が鉄系溶製材料のデータ，三 角形印が鋳造アルミニウム合金，丸印が粉末材料の DistaloyAE と AstaloyCrMである. 粉末材料は平面曲げによる 疲労強度のデータを用い，他の材料は回転曲げのデータを参 照した ${ }^{16,17)}$.

溶製材の場合，素材を鍛造一加工一浸炭焼入焼戻ーショッ トピーニングで疲労蚛度の向上を図っている.このショット ピーニング技術においては各社ノウハウを持っている.

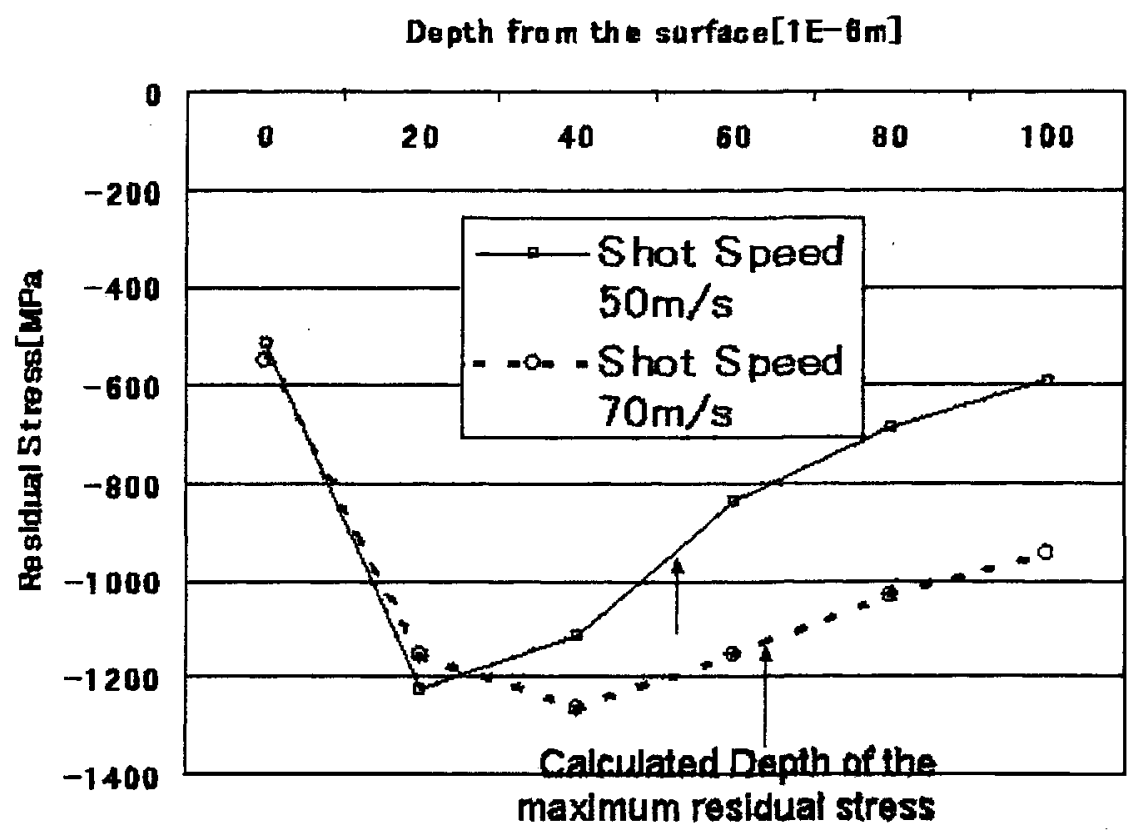

Fig.10 Profile of Residual Stress of Case hardened SCM420H after Shot Peening and Maximum Peek of Residual Stress when calculated.

Table 8 Fatigue strength of PM steels compared to case hardened wrought steel.

\begin{tabular}{|c|c|c|c|}
\hline Material & $\begin{array}{c}\text { After } \\
\text { Sintering or } \\
\text { Forging }\end{array}$ & $\begin{array}{c}\text { After } \\
\text { Carburizing } \\
\text { Tempering }\end{array}$ & $\begin{array}{c}\text { After } \\
\text { Shot Peening }\end{array}$ \\
\hline SCM420H & $410-460 \mathrm{MPa}$ & $520-550 \mathrm{MPa}$ & $800-850 \mathrm{MPa}$ \\
\hline DistaloyAE & $210-250 \mathrm{MPa}$ & $390 \mathrm{MPa}$ & $390 \mathrm{MPa}$ \\
\hline AstaloyCrM & $310-350 \mathrm{MPa}$ & $470 \mathrm{MPa}$ & $470 \mathrm{MPa}$ \\
\hline
\end{tabular}




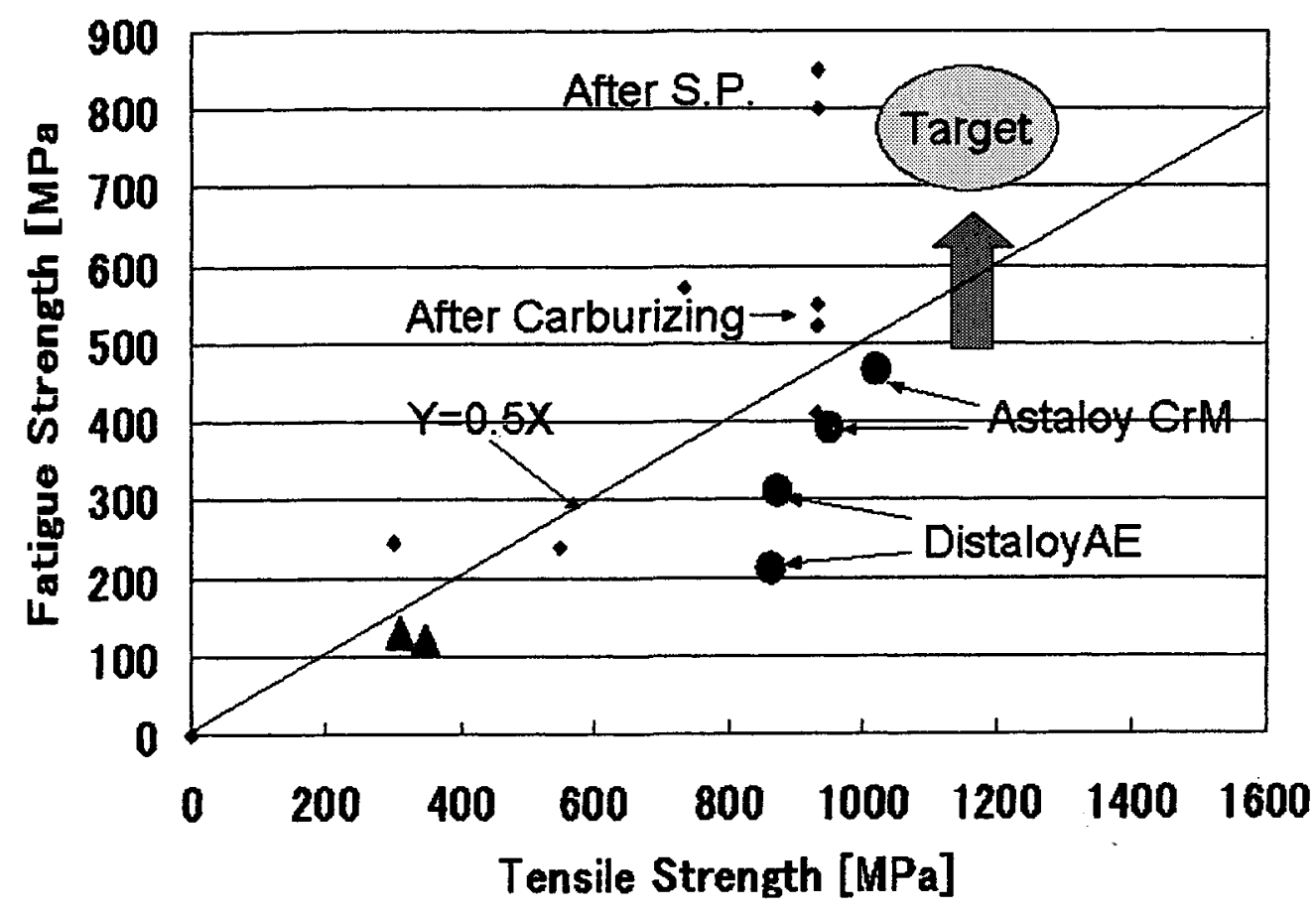

Fig.11 Fatigue Strength versus Tensile Strength of Cast Aluminum, Steel Plate, Case Hardening Steel and PM steels.

ショットピーニング技術そのものの日本における最初の応用 例は黎明期のトヨタ自動車製と富士重工業製の国産自動車に まで遡る。

一方，焼結体の場合，粉末成形一焼結一浸炭焼入焼戻一 ショットピーニングで疲労強度の向上を試みた.

結果は溶製材においては浸炭焼入にショットピーニングの 組合せにより格段の疲労強度向上が図れるのに焼結体におい ては組合せによる相乗勃果が本実験では得られなかった.

理由としては疲労強度の項でも述べているが，その他に試 験片の寸法効果も考慮せるばならない，次回の実験において は考慮すべき項目である。

焼結体の場合, 密度の影響と焼結体に適した浸炭焼入処理 を行い理想の金属組織を得る事が疲労強度向上に重要である と考えられる. 焼結体の疲労強度向上が今後の課題であり， 基礎データを蓄橨し工程を最適にチューニングすることによ り疲労強度の更なる向上を図って行く.

\section{4 ま と め}

（1）高温焼結鋼の疲労強度向上には浸炭焼入効果及びショット ピーニング効果が認められる.今までにない高疲労強度が 得られた。

DistaloyAE: 390Mpa, AstaloyCrM: 470Mpa であった.

(2) CSP 及び USP は焼結品の疲労強度向上並びに欠陮品の品 質安定化の作用が認められる.

(3) 焼結品への通常ショットピーニング処理では表面が粗くな
るにも関わらず, 疲労強度の向上を図ることができた. 条 件の最適化で更なる効果が期待できる.

(4) 超音波ショットピーニング処理は表面粗さを若干改善する 傾向があり，今まで懸念されてきた表面品質の低下の心配を 払拭できる方法である. 特に最表面の改質に期待できる。

(5) 疲労強度に奇与する圧縮残留応力は浸炭焼入とショット ピーニング処理との組合せにより最大となる.今回は組合 せ効果を得ることができなかったが，エッジ倠・寸法効 果を取り入れた表面近傍組織のチューニングにより更なる 改善を図りたい。

\section{謝 辞}

本実験の趣旨を御理解頂き，多大なる御協力を頂いた東洋 精鋼株式会社殿には心より御礼を申し上げます。

\section{文献}

1) O.Eriksson et al: Binder of new pre-alloyed $\mathrm{Cr} / \mathrm{Mo}$ steel powder released by Höganäs AB during 1998 Powder Metallurgy World Congress, 1.1-5.10.

2) U.Engström: "Evaluation of Sinter Hardening of Different PM Materials", Advances in Powder Metallurgy \& Particulate Materials, Part 6, (2000)5.147-5.157.

3) C.Lindberg et al: "Mechanical Propertes of Warm Compacted AstaloyCrM", PM2Tec (2000) MPIF, New York, 5.147-5.157.

4) K.Kanno, Y.Takeda, B.Lindqvist, S.Takahashi and K.Kanda: 
"Sintering of Prealloy 3Cr-0.5Mo Steel Powder in a Carbon/ Carbon Composite Mesh Belt Furnace", PM2Tec, Orlando, (2002) 13.14-13.22.

5) 本田忠敏: "鉄系焼結部品の疲労強度特性の現状と課題", 粉体および粉末冶金, 44(1997)475-482.

6) Kubaschewski Evans Alcock: "Metallurgical Thermo Chemistry", $4^{\text {th }}$ Edition, by Pergamon Press Ltd, Headington Hill Hall, Oxford 4 \& 5 Fitzroy Square, London W.1, 421-429.

7) 日本鉄鋼協会編: "鋼の熱処理 改訂5版", 丸善, (1979)708709.

8) A.Bergmark et al: "Fatigue Properties of Cu-C At Two Density Levels", PM Euro 2001, Volume 2, 110-115.

9）河本實他共著: "金属の疲れと設計", コロナ社, (1972)255256.

10) 中村宏他共著: "機械の疲労寿命設計", 盖賢堂, (1983)282.
11) H.Berns et al: "Influence of Residual Stresses on Crack Growth", Impact Surf Treat, (1986)31-44.

12) Y.F.Al-Obaid: "A Rudimentary Analysis of Improving Fatigue Life of Metals by Shot-Peening", Journal of Applied Mechanics, 57(1990)307-312.

13) 渡邊吉弘: "ショットピーニングのピーニング勃果に関す る基礎的研究", 博士論文, (1995).

14) 紅林豊, 秦野敦臣: "漫炭鋼の疲れ特性に及ぼす $\mathrm{Si}, \mathrm{V}$ の影 響 ", 電気製鋼, 67(1996)34-43.

15) 林暢彦, 東海林友紀: "強ショットピーニングの効果”,い すぶ技報，第87号，(1992)90-94.

16）軽金属協会編: " 自動車のアルミ化技術カイイド", 第 3 版, (1993)17-18.

17) 秦野敦臣, 並木邦夫 : “浸炭鋼の疲れ強さにおよぼす ショットピーニングの影響", 電気製鋼, 63(1992)22-31. 